\title{
The Pricked Embryo in the Medieval Tradition
}

\author{
C Beneduce ${ }^{1}$ \\ ${ }^{1}$ Radboud University, Nijmegen (NL)
}

submitted: Jan 11, 2017, accepted: Mar 7, 2017, EPub Ahead of Print: Mar 10, 2017, published: May 1, 2017

Conflict of interest: None

DOI: 10.24019/jtavr.16 - Corresponding author: Dr. Chiara Beneduce, c.beneduce@ftr.ru.nl

(C) 2016 Fondazione Vasculab impresa sociale ONLUS. All rights reserved.

\begin{abstract}
The medieval tradition transmitted the idea that an embryo, pricked with a needle in an early stage of its development, moves and shows a certain sensation activity. This article traces the history of this topos in the Middle Ages and up to William Harvey. The image of the pricked embryo was transmitted within three main frameworks: the discussions on the faculties of the soul, the problem of the localization of the sense of touch, and the issue of the corporeal localization of the common sense. The pricked embryo is a case in point to show the legacy of Aristotelian cardiocentrism well past the Middle Ages
\end{abstract}

Keywords Pricked embryo, Albert the Great, William Harvey, Aristotle, cardiocentrism.

\section{Introduction}

William Harvey (1578-1657), the physician famous for being the first to have accurately described the circulatory system, wrote a text on embryology and reproduction entitled Exercitationes de generatione animalium $^{1}$. In a passage of this work, he points out a physical 'paradox' according to which blood is formed in the embryo, moved, and 'soaked' with vital spirits before the formation of any organs apt to producing blood or movement. He also adds and specifies that sensation and movement are present in the fetus before the formation of the brain. In fact the fetus moves and contracts before the brain is visible, which proves that sensation and movement do not entirely originate in the brain ${ }^{[i]}$. Harvey also remarks that the embryo moves and senses before the formation of the brain or of other corporeal members because, if the embryo is slightly pricked ("leviter pungatur"), it moves and squirms ${ }^{[i i]}$.
The historian of science Walter Pagel (1898-1983) was the first to point out that "Harvey's method of demonstrating tissue irritability as independent of the brain by pricking the embryonic anlage with a needle was foreshadowed by an observation of Albertus Magnus in human foetuses ..." (Pagel 1966, p. 410) ${ }^{2}$. In other words, Pagel underlined that Harvey's image of the pricked embryo is already in Albert the Great (†1280) who seems to be the first to have introduced this image (Ibidem, pp. 410-411). Most importantly, he remarked that "it is not unlikely that Harvey was familiar with Albertus' text ..." (Ibidem, p. 411) since on the whole "...we have every reason to believe that Harvey was well acquainted with scholastic commentators of Aristotle ..." (Ivi).

In linking Harvey with Albert, Pagel referred to a passage of Albert's De animalibus that is couched in a broader discussion of abortion. In this passage, Albert points out that a certain movement can be observed when an embryo, aborted on the fortieth day and expelled from the mother's body, is pricked with a needle, thus showing that the fetus is animated at this early stage of development (Albert The Great 1916, lib. IX, tract. 1, cap. 3, 11. 18-21, p. 698$)^{3}$. As Pagel wrote, this passage is in turn based on Aristotle (384-322 BC) who describes not the image of the pricked embryo but the fact that the embryo aborted on the fortieth day is of a certain size (that of a large ant) and shows the presence of certain organs (limbs, penis, and eyes) (Aristotle, Hist. an. $)^{4}$. It is exactly on this basis that Pagel observed that Harvey's 'pricked embryo' is already in Albert, although "[i]n significance and purpose Albertus' observation is ... far removed from Harvey's ideas..." (Pagel 1966, p. 411) and "neither the experimental conditions nor the biological conclusions [of the two] are comparable" (Ivi), also because Albert deals with "... a 
much later stage in foetal development" (Ibidem, p. 410) than Harvey.

Against the background of Pagel's remark, I want to show more details of the tradition on the image of the pricked embryo in the late Medieval thought. This could also shed more light on the use of the image of the pricked embryo made by Harvey.

\section{The Pricked Embryo in the Medieval Tradition}

Besides Albert's passage in the De animalibus, there is a conspicuous set of late medieval texts (all later than Albert's) presenting the image of the pricked embryo and all in different contexts. This image seems to have been transmitted under three frameworks: the discussions on the faculties of the soul, the issues concerning the sense of touch, and the problem of the localization of the common sense.

\subsection{The Faculties of the Soul}

The first framework transmitting the image of the pricked embryo are the discussions on the 'parts' or faculties of the soul: vegetative, sensitive, and rational. The image is found in different types of texts, both theological and natural-philosophical (especially commentaries on the De anima), addressing those topics. More specifically, the image is found in a variety of 'classic' medieval problems on the soul, such as 1) whether the nutritive, sensitive, and rational powers (of the soul) should be considered as one soul or three distinct souls; 2) the way and the chronology according to which the faculties of the soul are 'produced' and embodied; and 3) the ontological status of the human being before he acquires the rational soul ${ }^{[i i i]} 5$.

The first example is in Albert the Great's De anima in a section where he shows that the vegetative, sensitive, and rational 'parts' of the soul are not three distinct souls (or three different souls). Among the arguments brought against this position, Albert explains there is one claiming that since the faculties of the soul are settled chronologically one after the other, it is not possible to consider all of them together as one substance. The pricked embryo is an example for this claim: the pricked embryo moves due to the sense of touch (namely, to the sensitive soul) before the rational soul is active ${ }^{[i v] 6}$.

The image of the pricked embryo in the discussions on the faculties of the soul also appears in the De anima of Roger Bacon († 1294), more specifically in a section devoted to the 'production' of the 'parts' of the soul. Bacon supports the idea that only the intellective soul is created, while the sensitive and nutritive souls are just naturally (per viam naturae) produced (producantur) from the potency of matter (de potentia materiae). The image of the pricked embryo is used to show that the nutritive and the sensitive souls function before the intellect is created. This means that the vegetative and the sensitive souls are not created at the same time as the intellective soul, otherwise we would have a duplication of the non-intellective parts of the soul: 1) a vegetative and a sensitive soul created together with the intellective soul and 2) a vegetative and a sensitive soul produced by the potency of matter before the creation of the intellective soul ${ }^{[\mathrm{v}] 7}$.

A third example is from the De anima of Matthew of Aquasparta ( $\uparrow 1302)$. He attempts to determine whether the human being, before the infusion of the ration soul, is 'human' according to another type of form, namely a nonrational form. His answer is negative. The image of the pricked embryo is inserted in one of the arguments listed in favor of the positive answer to the question: the embryo is animated and has the sense of touch, which is proved by pricking it. This makes him an animal (the sense of touch, in fact, according to Aristotle characterizes animals), but not a human being. Therefore before acquiring the rational soul, the embryo is in some not-yet-human species and is constituted by some not-yet-human form ${ }^{[\mathrm{vi}]}$.

The last example is found in Giles of Rome's Quodlibet. Giles († 1316) asks whether the human being, before the infusion of the rational soul, should be considered to belong to some (non-human) animal species. Giles' answer is positive. In his quaestio, he incidentally mentions the image of the pricked embryo in a complicated and technical digression on the issue of the plurality or unity of the soul ${ }^{\text {[vii] } 8}$. The pricked embryo appears again in a passage of Giles of Rome's Sentences commentary where he explains that the pricked embryo moves only when it is provided with the sensitive soul, while it does not move when it has only the vegetative soul ${ }^{[\text {viii] }] 9}$.

This list of texts shows that the image of the pricked embryo, used in different types of texts and for different purposes, had a certain fortune in the late medieval discussions on the faculties of the soul. It is relevant to notice that two of the examples listed above (Roger Bacon and Matthew of Aquasparta) explicitly refer to Aristotle as the source for the image of the pricked embryo ${ }^{[\mathrm{ix}]}$. This is especially evident in Matthew of Aquasparta's passage. In the Aristotelian works we do not find the image of the pricked embryo, but just the idea that the embryo possesses nutritive and sensitive functions in the early stages of its formation ${ }^{[x] 10}$, and that the fetus is able to sense thanks to the heart and before the formation of the other corporeal organs ${ }^{[\mathrm{xi}] 11}$. Despite the fact that the pricked embryo is nowhere to be found in Aristotle, we should take into account that at least some of the medieval authors transmitting the Albertinian image of the pricked embryo directly cited Aristotle as its source. 


\subsection{The Sense of Touch}

Two texts of the previous group connected the pricked embryo with the sense of touch ${ }^{[x i i]}$. In fact, the image of the pricked embryo can be also found in medieval issues concerning this sense. The main medieval questions concerning the sense of touch were: 1) what is the corporeal localization of touch; 2) in which medium does it perform its activity (and, more radically, whether or not touch needs a medium to function), and 3) to which of the four elements (air, water, earth, and fire) is touch more naturally connected. In medieval treatises of natural philosophy the five senses were in fact often paired with the four elements.

The first example in this conceptual framework is in the Parva naturalia of John of Jandun ( $\dagger$ ca. 1323) in a question discussing the connection between the sense of touch and the element of earth. In order to prove this connection, he shows that the sense of touch is corporeally located in the heart, which being very solid in order to bear the heat is dominated by the terrestrial element. Therefore, touch is dominated by earth, too. The image of the pricked embryo is used to show that touch is actually located in the heart since the embryo performs tactile sensation after the formation of the heart ${ }^{\text {[xiii] }] 12}$.

Even though our knowledge of late medieval commentaries on the Parva naturalia is still limited, it may be safe to generalize that the image of the pricked embryo was present in other medieval discussions on the sense of touch as they were addressed in those commentaries.

A second example is highly relevant. The pricked embryo - more precisely a pricked heart in a stage of foetal development - also appears in the De anima of John of St. Thomas (1589-1644), a contemporary of Harvey. In the section of his work on 'the potency, the act, and the medium of touch', he presents the Aristotelian idea that touch is localized in the heart, a position he ultimately rejects. In this framework, he presents an argument in favor of the Aristotelian position that runs as follows: the heart is formed in the living being before the brain and is immediately able to sense; this is proved by the fact that it palpitates and, if pricked, moves; therefore, the sense of touch is in the heart ${ }^{[\mathrm{xiv}] 13}$.

We can therefore find the image of the pricked embryo within medieval discussions on touch and in later natural-philosophical treatises even contemporary to Harvey.

\subsection{The Localization of the Common Sense}

The third framework transmitting the image of the pricked embryo is found in the questions on the localization of the common sense in late medieval commentaries on the De anima and, above all, on the Parva naturalia. These questions were especially meant to solve the controversial issue on the corporeal localization of sensation; the 'sensus communis', in fact, according to the Aristotelian and Scholastic tradition, is the ultimate perception ability whose primary role is to coordinate and organize the perceptual elemental stimuli coming in from the external world to be used for higher internal mental processes. This issue opposed the Aristotelian-philosophical tradition to the Galenic-medical tradition that located the common sense, respectively, in the heart and in the brain. The solution of this problem, among both philosophers and physicians, was mostly oriented at reconciling the two traditions.

In this framework, the image of the pricked embryo occurs several times in the texts of the philosophers commenting on Aristotle's natural philosophy, especially the De anima and the Parva naturalia. They most often insert the image when listing the arguments in favor of the Aristotelian cardiocentric position, the one they ultimately support. In fact, the Aristotelian commentators argue that sensation cannot be localized in the brain, since the pricked fetus moves and senses before the formation of this organ. The embryo shows sensation abilities because of the heart, which is the first organ to be formed in human beings. In chronological order, we find the image of the pricked embryo in a set of questions on De iuventute et senectute, De morte et vita not safely ascribed to Siger of Brabant $(\dagger$ $1284)^{[\mathrm{xv}] 1415}$, in Simon of Faversham's († 1306) Parva naturalia (especially De somno et vigilia) ${ }^{[\mathrm{xvi}] 16}$, in John of Jandun's Parva naturalia (again De somno et vigilia) ${ }^{[\mathrm{xvii}] 17}$ , and in John Buridan's († ca. 1360) De anima ${ }^{[\mathrm{xviii}] 18}$.

As in the case of the sense of touch, the image of the pricked embryo used in the discussions on the localization of the common sense seems to have had a special circulation in the tradition of the commentaries on the Parva naturalia. We can likely expect to find more examples of the use of this image in that tradition.

\section{Conclusions}

The image of the pricked embryo clearly had a wide circulation in the Middle Ages. Albert the Great is the first author in which we have been able to find this image, but the main inspiration was undoubtedly Aristotelian. Based on the examples provided, two clear and influential points from Aristotelian natural philosophy appear to have persisted throughout the Middle Ages: a) the general idea that the embryo is able to perform vegetative and sensitive functions in the early stages of its formation and b) the more specific idea according to which sensation is located in the heart given that the embryo shows sensory abilities before the formation of the brain when only the heart is formed. This Aristotelian background clearly explains why the image of the pricked embryo had such fortune when medieval authors considered the Aristotelian cardiocentrism about 
the localization of the sense of touch or the localization of the common sense. Moreover among all the textual traditions, the commentaries on the Parva naturalia seem to have been the most important vehicle for the transmission of the image of the pricked embryo. These commentaries spread the positions both on the localization of the sense of touch and on the localization of the common sense. However, the image of the pricked embryo is also present in texts addressing other medieval topics related to the 'science of the soul' - here, more theoretical than biological - such as the formation of and the relationships between the faculties of the soul.

We can safely state that the image of the pricked embryo is an actual topos of medieval philosophy that was transmitted later on to the early-modern period, both to philosophers and physicians of the sixteenth century, as the texts of John of St. Thomas and William Harvey testify. Harvey's passage in the Exercitationes, then, has to be contextualized in a broader and long-standing tradition that persisted well into his own times. More specifically, Harvey did not necessarily have the passage from Albert's De animalibus in mind, but he most likely included in his text a common and shared topos ${ }^{[\mathrm{xix}]}$. We cannot even exclude that Harvey read about the image of the pricked embryo from one of his contemporaries perhaps in a philosophical treatise of his time.

More generally, the case of the pricked embryo testifies to the longue durée of medieval naturalphilosophical topics into the Modern Era, especially to life of discussions on Aristotelian cardiocentrism, a core-aspect of medieval biological thought which lasted well past the Middle Ages.

\section{Acknowledgments}

I am grateful to Frederik Bakker and Elena Nicoli for their help with the Latin texts.

\section{Endnotes}

[i] "Videtur praeterea paradoxon, sanguinem fieri et moveri, spirituque vitali imbui; antequam ulla organa sanguifica, vel motiva existerint [exstiterint ed.]. Nec minus novum, atque inauditum, inesse sensum ac motum in foetu, priusquam cerebrum exstructum fuerit. Movetur enim fetus, contrahit et explicat sese, cum pro cerebro adhuc nihil conspicuum est, praeter aquam limpidam" (Harvey 1662, p. 243). "Moreover, it seems to be a paradox that blood is formed, moved, and imbued with a vital spirit before the formation of any organs apt to producing blood or movement. Nor is it less strange or unheard-of that sensation and movement are present in the fetus before the formation of the brain. For, the fetus moves, contracts, and unfurls itself when in the place of the brain nothing yet is visible except for clear water". All translations of the Latin passages are mine. When necessary, I modified the punctuation of the Latin text.

[ii] "... cumque cerebrum nil aliud, quam aqua limpida est; si modo leviter pungatur, instar vermis vel erucae, sese obscure movet, contrahit, et contorquet; ut sentire ipsam evidenter pateat" (Harvey 1662, p. 245). "... when the brain is nothing but clear water, if [the embryo] is only slightly pricked, it vaguely moves, contracts, and squirms like a worm or a caterpillar, so that it is clearly evident that it feels".

[iii] The following examples (in this first group of texts) have been collected by A.-J. Gondras in his edition of Matthew of Aquasparta's De anima (Matthew of Aquasparta 1961, footnote 'm', p. 77). [iv] "Probant autem hoc ex eo quod embria prius tempore trahunt nutrimentum ex sanguine menstruoso, quam sentiant. Trahens autem nutrimentum et convertens in speciem nutriti, non est nisi anima vegetabilis. Similiter autem embria puncta contrahuntur, quod non fit sine sensu tactu ..." (Albert the Great 1968, libr. 3, tract. 5, cap. 4, 11. $23-29$, p. 248a). "However, they prove this by the fact that embryos take nutriment from the menstrual blood before sensing. But taking the nutriment and transforming it into the species of what is nourished, that cannot happen without the vegetative soul. However, in the same way, the embryos contract when pricked which would not happen without the sense of touch ...".

[v] "Item, arguunt per experienciam. Nam embrio ante infusionem anime racionalis nutritur et crescit, et si pungatur sentit, et hoc sciunt mulieres ex parte in talibus, et Aristoteles hoc vult in libro De animalibus, et aliis auctores concordant. Manifestum est igitur quod anima vegetativa et sensitiva sunt in embrione hominis antequam intellectiva producatur". (Bacon 1911, pars 4, dist. 3, cap. 1, 11. 16-22, p. 283). "In addition, they argue on the basis of experience. For the embryo, before the rational soul is poured in, nourishes itself and grows, and, if it is pricked, it feels [it]. And women know this partly in such circumstances, and Aristotle implies this in the work On Animals, and other authoritative sources agree. It is evident therefore that the vegetative and sensitive souls are in the human embryo before the intellective soul is produced".

[vi] Matthew does not better specify what he means by the "not-yet-human" species and form; "Item, secundum Philosophum, II De anima, tactus est primus sensus per quem animal est animal; ergo omne animatum, in quo est sensus tactus, est animal; sed embryo est animatus et habet sensum tactus; ergo est animal; sed non est homo; ergo est in aliqua specie constitutus per aliquam formam. 
Quod autem in embryone sit tactus, [manifestus est, quia] dicit Philosophus: si pungatur, contrahitur" (Matthew of Aquasparta 1961, q.5, p.77) . "Moreover, according to the Philosopher, in the second book of his On the Soul, touch is the first sense thanks to which an animal is [qualified as] an animal; therefore, every animated being in which there is the sense of touch is an animal; but the embryo is animated and has the sense of touch, therefore it is an animal; but it is not human; therefore it is constituted in a certain species by means of a certain form. That in the embryo there is touch [clearly appears since] the Philosopher says: if it is pricked, it contracts".

[vii] "Respondeo dicendum fuisse opinionem quorumdam in embrione hominis non esse substantia animae sensitivae vel vegetativae ante infusionem animae rationalis. Quod autem ibi oporteat opera vitae, quando embrio ante infusionem animae rationalis augmentatur vel etiam quando apparent ibi opera sensus; quandoquidem embrio ante infusionem animae si pungatur se retrahat, (ut dicunt) hoc esse per virtutem vegetativam, vel sensitivam, absque substantia sensitiva vel vegetativa" (Giles of Rome 1946, I, q.14, p. 29). "I answer that it must be said that some people were of the opinion that in the human embryo there is no substance of a sensitive and vegetative soul before the rational soul is poured in. But [that], because life's operations must [be] there, since the embryo, before the rational soul is poured in, grows, and also since sense's operations are manifest there - for the embryo, before the soul is poured in, if it is pricked, pulls back, this is (as they say) because of the vegetative or the sensitive virtue, without the sensitive or the vegetative substance".

[viii] "... embrio hominis primo vivit vita plantae et est ibi essentia animae vegetativae similis animae plantae et sunt ibi potentiae illius quia nutritur et augmentatur embrio hominis sicut nutritur [nutritivus ed.] et augmentatur planta et quandiu vivit vita plantae, si pungeretur, non sentiret, sicut nec sentit planta. Postea post vitam plantae incipit vivere embrio vita animalis, et incipit habere animam sensitivam, nec habet propter hoc duas animas quia adveniente anima sensitiva cedit anima plantae ... cedente illo primo vegetativo, et introducto sensitivo, hoc sensitivum secundo introductum dabit embrioni quicquid dabat primum vegetativum et adhuc amplius ... quod dabit ei quod sentiat ut ex tunc si pungeretur sentiret et retraheret se" (Giles of Rome 1581, dist. 19, q.1, art. 4, p. 128b). "... the human embryo first lives the life of a plant and the essence of the vegetative soul is there, similar to the soul of a plant, and the capacities of that [i.e., of the vegetative soul] are there, since the human embryo nourishes itself and grows, just as a plant nourishes itself and grows, and as long as it lives the life of a plant, if it is pricked, it does not feel [it], just as a plant does not feel. Then, after the plant's life, the embryo starts living the life of an animal, and begins to have a sensitive soul, and yet does not, for this reason, have two souls, since, when the sensitive soul comes, the plant's soul goes away. ... Once that first vegetative [principle] is gone, and once the sensitive [one] is introduced, this sensitive [principle] introduced afterwards will give to the embryo everything the first vegetative [principle] used to provide and even more ... [the sensitive principle] will give to it [i.e., to the embryo] the capacity of sensing so that from that moment, if it is pricked, it would pull itself back".

[ix] See endnotes [v] and [vi].

[x] See Arist., De gen. an., II, 3, 736a29-736b2. See the translation in Barnes' edition: "[it is also necessary to decide $C B$ ] concerning the soul in virtue of which an animal is so called (and this is in virtue of the sensitive part of the soul) - does it exist originally in the semen and in the embryo or not, and if it does whence does it come? For nobody would put down the embryo as soulless or in every sense bereft of life (since both the semen and the embryo of an animal have every bit as much life as a plant), and it is productive up to a certain point. That then they possess the nutritive soul is plain (and plain is it from the discussions elsewhere about soul why this soul must be acquired first). As they develop they also acquire the sensitive soul in virtue of which an animal is an animal ..." (Aristotle 1984, pp. 1142-1143).

[xi] See Arist., De part. an., III, 4, 666a16-22. See the translation in Barnes' edition: "Again, as neither the blood itself, nor yet any part which is bloodless, is endowed with sensation, it is plain that that part which first has blood, and which holds it as it were in a receptacle, must be the primary source. And that this part is the heart is not only a rational inference, but is also evident to the senses. For no sooner is the embryo formed, than its heart is seen in motion as thought it were a living creature, and this before any of the other parts, it being, as thus shown, the starting-point of their nature in all animals that have blood". (Aristotle 1984, p. 1038).

\section{[xii] See endnotes [iv] and [vi].}

[xiii] "Item probatur aliter illud dominium quia nos videmus quod organum tactus est circa corpus, immo etiam in corde est organum tactus quod probatur per embrionum formationem, qui sentiunt solo corde formato et si pungatur retrahit se et dilatatur, ..." (John of Jandun 1557, q.15, f. 9ra). "Moreover, this dominium is proved in another way because we see that the organ of touch is around the body or, even better, that the organ of touch is in the heart, which is proved by the formation of the embryos. [The embryos can] feel when only the heart is already formed and, [if the heart] is pricked, pulls itself back and dilates itself ...".

[xiv] "Est tamen pro Aristotele argumentum, quia cor prius formatur in animali quam cerebrum et statim sentit, quia palpitat, et si ibi pungatur, se retrahit; ergo sensus tactus originatur a corde. Similiter decapitato homine adhuc 
cor sentit et brevi tempore palpitat et si pungatur, sentit. Ergo sensus tactus radicatur in corde" (John of St. Thomas 2008, vol. III, pars. IV, q. V, art.6, p. 163a). "Nevertheless, there is an argument in favor of Aristotle because the heart is formed in the animal before the brain and it immediately feels, since it palpitates and, if it is pricked there, pulls itself back; then, the sense of touch originates from the heart. In the same way, if a human being is decapitated, the heart still feels and, for a short time, palpitates, and, if it is pricked, it feels [it]. Therefore, the sense of touch takes root in the heart".

[xv] The questions have been ascribed to Siger of Brabant by F. Van Steenberghen (Van Steenberghen 1931). On these questions and their doubtful attribution to Siger of Brabant, see P. De Leemans (De Leemans 2011, esp. p. 920). Van Steenberghen offers a summary of q.4 (Utrum sensitivum commune sit in corde), found at $\mathrm{f}$. $72 \mathrm{rb}$ of the ms. München, Bayerische Staatsbibliothek, Clm. 9559. The relevant part of his summary runs as follows: "Le sens commun se trouve premièrement dans le coeur, car c'est là que se manifeste la première activité sensitive (dans l'embryon), alors que les autres organes ne sont pas encore formés: 'quoniam ... si pungatur, retrahit se"' (Van Steenberghen 1931, p. 265).

[xvi] See q. 5 (Utrum sensitivum primum sit in corde): "Dicendum est ad hoc quod sensitivum primum est in corde. Et ratio huius est, sicut Philosophus dicit primo De morte et vita, <quod $>$ secundum eandem partem animal est animal $<$ atque $>$ primo vivit et nutritur. Et ratio huius est quia nos videmus quod quaedam animalia decisa vivunt ... Tertio hoc determinatur sic: animal est animal per hoc quod habet [[hoc]] animam sensitivam; ... Ex hoc arguitur: animal est animal per hoc quod habet animam sensitivam, sed anima sensitiva non invenitur sine sua virtute, et virtus sensitiva non reperitur sine primo sensitivo; ergo animal est animal propter sensitivum primum; nunc autem primum sensitivum in animali est ipsum cor, cuius ratio est quia formato corde non formatis aliis partibus ipsum retrahit se si pungatur, et hoc non esset nisi sensitivum esset in ipso; sed ideo etc." (Simon of Faversham 2013, esp. pp. 113-115). "On this, it must be said that the first principle of sensing is in the heart. And the reason for that is, as the Philosopher says in the first section of his work On Death and Life, that thanks to the same part due to which the animal is an animal, it lives and nourishes itself. And the reason for this is that we see that some animals, when cut, [can] live ... Third, this is proved in the following way: an animal is an animal due to the fact that it has a sensitive soul ... from this it is said: an animal is an animal since it has a sensitive soul, but the sensitive soul is not found without its virtue, and the sensitive virtue is not found without the first principle of sensing; therefore an animal is an animal thanks to the first principle of sensing; but, now, the first principle of sensing in the animal is the heart itself; the reason being that when [only] the heart is formed but the other [corporeal] parts are not [yet] formed it [i.e.; the animal] pulls itself back if it is pricked, and this would not happen if the principle of sensing would not be in it. But for this reason etc.".

[xvii] See q. 9 (Utrum sensus communis sit in corde): "Dimissis opinionibus aliorum, dico breviter quod sensus communis est in corde quia nullus sensus potest esse sine sensu communi et quicquid sentit potest iudicare se sentire illud quod sentit et cognoscere ad minus quo ad suam sensationem. Sed cor primo formatum nullo alio membro formato sentit, sicut patet per experientiam, si pungatur, retrahit se, ergo saltem habet tactum et sic oportet quod habeat sensum commune; et sic sensus communis est in corde quia si esset in cerebro, ut in suo proprio subiecto et organo, tunc cum ipsum cerebrum non est formatum, non sentiret cor, quod patet esse falsum" (John of Jandun 1557, q.9, f. 37ra). "Setting aside the opinions of others, I briefly say that the common sense is in the heart because no sense can be without the common sense and everything that feels can judge itself to be feeling what it is feeling and know at least as far as its sensation [goes]. But the heart, formed first, when no other member if formed yet, [can] feel as is evident from experience, [because] if it is pricked, it pulls itself back, [and] therefore, at least, it has [the sense of] touch and so must have the common sense; and so the common sense is in the heart, because if it were in the brain, as in its proper place and organ, then, when the brain itself is not formed, the heart would not feel anything, which is patently false".

[xviii] See q. 24 of the second book in the third version of Buridan's commentary (Utrum organum sensus communis est in corde vel in cerebro): "Item alia experientia est quod in formatione embrionis prima pars apparens nobis formata est cor, quod iam ante apparentem formationem aliorum membrorum habet vitam et sensum, nutritur enim et augetur. Et si pungatur, commovetur ..." (John Buridan 1984, II, q. 24, p. 395). "And another experience is that in the formation of the embryo the first part that appears to us to be formed is the heart, which, already before the visible formation of the other members, has its own life and sense, nourishes itself and grows. And, if it pricked, it moves ...".

[xix] We can then scale down Pagel's claim that Albert deals with "... a much later stage in foetal development" than Harvey. Harvey could have had the passage from Albert's De anima in mind, instead of that from the De animalibus. See endnote [iv] and reference 3.

\section{References}

1) Harvey W. Exercitationes de generatione animalium. Amsterdam: Ioannes Ravesteynius; 1662.

2) Pagel W. Harvey, Foetal Irritability - and Albertus Magnus. Medical History. 1966; Oct;10(4):409-411.

3) Albert the Great. De animalibus libri XXVI. Stadler H, editor. Münster: Aschendorff; 1916. 
4) Aristotle, Hist. an., VII, 4, 583b15-20.

5) Matthew of Aquasparta. Quaestiones diputatae De anima XIII. Gondras A-J, editor. Paris: Vrin; 1961.

6) Albert the Great. De anima. Stroick C, editor. Münster: Aschendorff; 1968.

7) Roger Bacon. Liber primus communium naturalium. In: Steele R, editor. Opera hactenus inedita Rogeri Baconi. Oxford: Oxford University Press; 1911.

8) Giles of Rome. Quodlibeta. Leuven: Hieronymus Nempaeus; 1646.

9) Giles of Rome. In secundum librum Sententiarum quaestiones. Venice: Franciscus Zilettum; 1581.

10) Aristotle, De gen. an., II, 3, 736a29-736b2. Aristotle. Generation of Animals (translation), In: Barnes J, editor. The Complete Works of Aristotle, vol. I. Princeton: Princeton University Press; 1984, pp. 1142-1143.

11) Aristotle, De part. an., III, 4, 666a16-22. Aristotle. Parts of Animals (translation), In: Barnes J, editor. The Complete Works of Aristotle, vol. I. Princeton: Princeton University Press; 1984, p. 1038.

12) John of Jandun. De sensu et sensato. In: Quaestiones super Parva naturalia. Venice: Hieronymus Scotus; 1557.
13) John of St. Thomas. Corpus Philosophicus Thomisticus. Reiser B, editor. Hildesheim: G. Olms; 2008.

14) Van Steenberghen F. Siger de Brabant d'après ses oeuvres inédites, vol. 1: les oeuvres inédites. Institut Supérieur de Philosophie: Louvain; 1931.

15) De Leemans P. Parva naturalia, Commentaries on Aristotle's. In: Lagerlund H. editor. Encyclopedia of Medieval Philosophy. Philosophy between 500 and 1500 . Dordrecht: Springer 2011; pp. 917-923.

16) Simon of Faversham. Quaestiones super librum De somno et vigilia. Ebbesen $\mathrm{S}$, editor. Simon of Faversham, Quaestiones super librum De somno et vigilia. An Edition. Cahiers de l'Institut du Moyen-Âge grec et latin, 2013;82:90-145.

17) John of Jandun. De somno et vigilia. In Quaestiones super Parva naturalia. Venice: Hieronymus Scotus; 1557.

18) John Buridan. Quaestiones De anima, tertia lectura. In: Sobol P, editor. John Buridan on the Soul and Sensation. An Edition of Book II of his Commentary on Aristotle's Book on the Soul with an Introduction and a Translation of Question 18 on Sensible Species. Unpublished Ph.D. thesis. Indiana University; 1984. 